\title{
Black twig borer, Xylosandrus compactus (Eichhoff), a potential threat to coffee production
}

\author{
El barrenador de ramas, Xylosandrus compactus (Eichhoff), \\ una amenaza potencial para la producción de café
}

\begin{abstract}
Amanda C. Túler ${ }^{1}$; Wilson R. Valbon²; Hígor S. Rodrigues ${ }^{3}$; Luína R. Noia ${ }^{4}$; Lucas M. L. Santos ${ }^{5}$; Isac Fogaça ${ }^{6}$; Vando M. Rondelli; Abraão C. Verdin Filho ${ }^{8}$
\end{abstract}

\section{ARTICLE DATA \\ 1 M.Sc. Departamento de Entomologia e Acarologia, Escola Superior de Agricultura "Luiz de Queiroz", São Paulo,Brasil, amandatuler@usp.br \\ 2 M.Sc. Departamento de Entomologia, Universidade Federal de Viçosa, Minas Gerais, Brasil, wilson. valbon@ufv.br \\ 3 M.Sc. Departamento de Entomologia, Universidade Federal de Viçosa, Minas Gerais, Brasil, higor.souza@ ufv.br. \\ 4 M.Sc. Departamento de Agronomia, Universidade Federal do Espírito Santo, Espírito Santo, Brasil, luina. noia@ufes.br \\ 5 B.Sc. Departamento de Fitotecnia e Zootecnia Universidade Estadual do Sudoeste da Bahia, Bahia, Brasil, lucasagrouesb@gmail.com \\ $6 \quad$ M.Sc. Autarquica de Assistência Técnica e Extensão Rural do Estado de Rondônia, Rondônia, Brasil, fogacaisac@gmail.com \\ 7 DSc. Departamento de Agronomia, Universidade Federal de Rondônia, Rondônia, Brasil, vando. rondelli@unir.br \\ 8 M.Sc. Instituto Capixaba de Pesquisa, Assistência Técnica e Extensão Rural, Fazenda Experimental de Marilândia, Espírito Sato, Brasil, verdin.abcfilho@ gmail.com}

Cite: Túler, A., Valbon, W., Rodrigues, H., Noia, L., Santos, L., Fogaça, I., Rondelli, V., \& Verdin Filho, A. (2019). Black twig borer, Xylosandrus compactus (Eichhoff), as a potential threat to the coffee production. Revista de Ciencias Agrícolas. 36(E). 9-20. doi: https://doi.org/10.22267/rcia.1936E.102

Received: Jun 152019.

Accepted: September 172019.

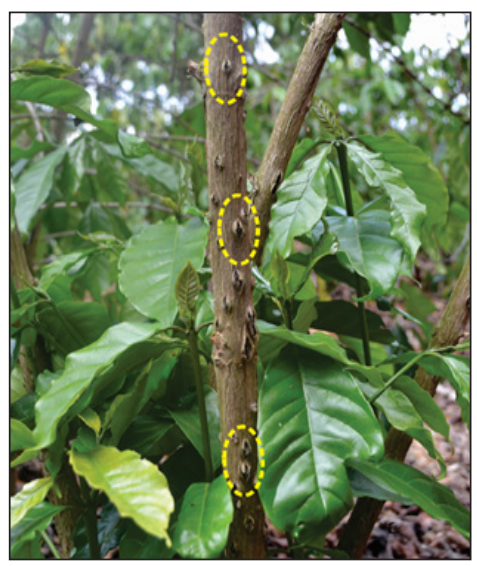

ABSTRACT

In robusta coffee, Coffea canephora, the black twig borer Xylosandrus compactus (Eichhoff) (Coleoptera: Curculionidae) causes considerable damage. Although this has been reported in many crops for years in Brazil, recently, the injury caused by $X$. compactus in coffee has been ignored. This present study aimed to report the current status of $X$. compactus in Brazil, and to investigate its attack frequency in different robusta coffee genotypes. In this study, we reported the occurrence of $X$. compactus in robusta coffee plants in the state of Rondônia for the first time. We also evaluated the occurrence of this pest in different robusta coffee genotypes in the state of Espírito Santo. In all plants, the plagiotropic branches were attacked; however, the genotypes G2, G6, G8, G20, G48, G50, G51 and G52 showed a high number of attacked plagiotropic branches, whereas the genotypes G24 and G41 showed a low attack frequency. Thus, these can be promising candidates for pest resistance studies. Moreover, it was reported that Almeidea rubra, Alseis floribunda, Plinia grandifolia and Casearia Sylvestris can serve as hosts of $X$. compactus. Thus, our findings suggest that $X$. compactus is a threat to coffee production, and that future studies are necessary to find appropriate tools for its management.

Key words: ambrosia beetle, Curculionidae, host plants, pest insect, Robusta coffee, Scolytinae

\section{RESUMEN}

En el café robusta, Coffea canephora, el barrenador de las ramas Xylosandrus compactus (Eichhoff) (Coleoptera: Curculionidae) causa daños considerables. Aunque esto se ha reportado en muchos cultivos durante años en Brasil, recientemente, la lesión causada por $X$. compactus en el café ha sido ignorada. El presente estudio tuvo como objetivo reportar el estado actual de X. compactus en Brasil e investigar su frecuencia de ataque en diferentes genotipos de café robusta. En este estudio, reportamos la aparición de $X$. compactus en plantas de café robusta en el estado de Rondônia por primera vez. También evaluamos la ocurrencia de esta plaga en diferentes genotipos de café robusta en el estado de Espírito Santo. En todas las plantas, las ramas plagiotrópicas fueron atacadas; sin embargo, los genotipos G2, G6, G8, 
Túler et al.- Xylosandrus compactus impairs coffee plants.

G20, G48, G50, G51 y G52 mostraron un alto número de ramas plagiotrópicas atacadas, mientras que los genotipos G24 y G41 mostraron una baja frecuencia de ataque. Por lo tanto, estos pueden ser candidatos prometedores para estudios de resistencia a plagas. Además, se reportó que Almeidea rubra, Alseis floribunda, Plinia grandifolia y Casearia sylvestris pueden servir como huéspedes de X. compactus. Por lo tanto, nuestros hallazgos sugieren que X. compactus es una amenaza para la producción de café, y que son necesarios estudios futuros para encontrar herramientas apropiadas para su manejo.

Palabras clave: escarabajo ambrosía, Curculionidae, plantas hospederas, insecto plaga, café Robusta, Scolytinae.

\section{INTRODUCTION}

Brazil is the world's largest producer and exporter, as well as the second largest consumer of coffee, especially Coffea arabica (L.) (Rubiacaea) (arabica coffee) and Coffea canefora (Pierre ex Froehner) (Rubiacaea) (conilon and robusta coffee) (Conab, 2018). However, the increase of reported yield losses caused by attacks of Xylosandrus compactus (Eichhoff) (Coleoptera: Curculionidae), also known as the black twig borer or the ambrosia beetle, in Brazil (Fornazier et al., 2016) and other Neotropical regions (Bukomeko et al., 2018) can affect coffee production and consumption. The potential of this insect as a pest and its biological behavior in coffee trees has not been adequately studied in Brazil. Climatic conditions, the presence of alternative hosts, and its lack of natural enemies may favor the maintenance and development of these insects in the field (Oliveira et al., 2008; Greco and Wright, 2015; Egonyu et al., 2017).

Xylosandrus compactus is native to Southeast Asia, but has a pantropical distribution throughout Africa, Asia, South America, and Southeastern United States (Rabaglia et al., 2006). Recently, its existence has been reported in Europe (Vannini et al., 2017). $X$. compactus affects more than 220 plants of about 62 families (Ngoan et al., 1976), including species of economic importance (Kagezi et al., 2014). In addition, it has been reported that the presence of $X$. compactus and its associated fungi in natural environments can cause serious damage to some tree species (Garonna et al., 2012; Vannini et al., 2017).

This insect has been observed in Brazil for more than 20 years, and has been reported in different plants including Theobroma cacao (L.) (Sterculiaceae) (Mendes et al., 1979), Mangifera indica (L.) (Anacardiaceae) (Carvalho et al., 1999) and Annona muricata (L.) (Annonaceae) (Oliveira et al., 2008). For C. canephora, the occurrence of $X$. compactus has been reported in the states of Bahia and Espírito Santo (Oliveira et al., 2008; Fornazier et al., 2016).

These pests infest plants by boring into the branch and introducing symbiotic fungi inside the host plants. Different fungi have been described as associating with $X$. compactus, including Fusarium solani, Ambrosiella xylebori, and Ambrosiella macrospora (Ngoan et al., 1976; Batra, 1985; Egonyu and Torto, 2018). These symbiotic fungi are essential for larval development, serving as a food source. Moreover, these fungi can cause severe plant injury as they can lead to the development of diseases (Batra, 1985; Bhat and Sreedharan, 1988; Brader, 1964).

Physiologically stressed trees or diseased plants are preferred by ambrosia female beetles, and their presence usually serve as an 
indicator of weakened trees, but $X$. compactus is one of the few species in which ambrosia beetles infest healthy plants (Dixon et al., 2003). Aside from its preference for healthy hosts, $X$. compactus remains in internal galleries where they are less conspicuous. Thus, taken together, these characteristics make the management of this species in the field a complex task.

Because of the lack of information regarding the black twig borer's behavior in robusta coffee, this study was conducted to report the current status of $X$. compactus as a pest in the main coffee producer states in Brazil (Espírito Santo and Rondônia). Furthermore, because of the recurrent presence of $X$. compactus in Espírito Santo, we evaluated its attack frequency in different robusta coffee genotypes in the field.

\section{MATERIALS AND METHODS}

\section{Insect collection, identification and image} recording. The occurrence and injury of $X$. compactus in robusta coffee plants was recorded in both Brazilian states, Rondônia and Bahia. In the state of Rondônia, 30 specimens were collected in the municipality of Cacoal (11.307806S, 61.492806W) by manually obtaining random samples V06, 25, 08, 07 and R22 clones. In the state of Bahia, insects and attacked branches were collected in the municipality of Eunápolis (16.365556S, $39.313611 W$ ) in both the V02 (Vitoria Incaper) clone and the G35 variety. In the state of Espírito Santo, insects and attacked branches were collected in the municipality of Marilândia (19.404681S, 40.538747W), and ten genotypes (G2, G6, G8, G20, G24, G41, G48, G50, G51 and G52).

The collected materials were taken to the Department of Entomology and Acarology at the Luiz de Queiroz College of Agriculture (ESALQ/USP, Piracicaba, São Paulo, Brazil) for identification and image recording. For identification, were selected six specimens, three female and three males, from each locality, Cacoal, Eunápolis and Marilândia. The specimens were identified based on their morphological characteristics using the taxonomic keys of Wood (1982), and by comparison with voucher specimens from the University of Florida UF Gainesville (\#4463). After identification, these insects were deposited in the Museum of Entomology of ESALQ (vial \#6990). In order to show the $X$. compactus individual and its effects on coffee branches, images of the insects, as well attacked branches containing these insects, were recorded using a stereo microscope (Leica M205C) equipped with a Leica DFC 450 camera.

The second group of collected material in the state of Bahia were taken to the Department of Entomology at the Federal University of Viçosa (UFV, Viçosa, Minas Gerais, Brazil) in order to record the development stages of insects. Firstly, three days after collection, were taken branches from the V02 clone with an active attack of alive insects within the galleries by observing the presence of wood dust around gallery entrance. Inspection and image recording were performed immediately after selection and were done every seven days in order to show all development stages egg, larva, pupa, and adult; these were done for approximately 24 days (Greco and Wright, 2015). For image recording, fifteen branches were used, and among the images, ones with the higher resolutions were included in the results section. The presence of $X$. compactus in the collected branches using a LX-60 specimen radiography system equipped with a digital camera (Faxitron X-Ray Corp., Wheeling, IL, USA), following the same methodology used by Haddi et al. (2015). 
Insect attack in robusta coffee and native plants. The mean number of attacked branches by $X$. compactus was evaluated in different robusta coffee genotypes. The study was conducted at the Experimental Field of "Incaper" (Institute of Espírito Santo for Research, Technical Assistance and Rural Extension), in Marilândia, Espírito Santo, Brazil (19.404681S, 40.538747W, at an altitude of $137 \mathrm{~m}$ ). Based on the recurrent attack of $X$. compactus in robusta coffee and the uniformity of the coffee crop (i.e., age and physiological condition), were selected of germplasm bank of Incaper with 10 genotypes to conduct the investigation. The C. canephora genotypes evaluated were $\mathrm{G} 2$, G6, G8, G20, G24, G41, G48, G50, G51 and G52. The evaluations were made during the dry season. The coffee plants were sown to a space of $3.0 \times 1.0 \mathrm{~m}$ and approximately 12.000 orthotropic stems per hectare, afterwards, the Cyclic Pruning Program for Conilon Coffee (CPPCC) was conducted, which maintained four new orthotropic stems per plant (Verdin Filho et al., 2014). Furthermore, based on the high infestation of $X$. compactus in clones of the "Vitoria Incaper 8142" variety previously observed, were selected the clone V06 to record the attack in orthotropic branches. These coffee plants were planted and evaluated under the same conditions as the other genotypes.

All orthotropic and plagiotropic branches that is to say, vegetative and production branches, respectively attacked by the insect were evaluated. Branches that were either recently attacked or those showing any initial perforations caused by adults were evaluated and the number of attacked branches was counted. The evaluations were conducted during the post-harvest period (September), which was chosen because it coincides with the peak of adult insects inside the galleries (Egonyu et al., 2016). A randomized complete block design with four replicates was used for the analysis, with each replicate had three plants.

In order to check possible host plants, a screening of the native host trees present near the study area was made. Specimens were collected and dried according to normal plant collection procedures (Peixoto and Maia, 2013), and identified using specialized literature and collections of the VIES (Thiers 2015), as well as the virtual herbarium REFLORA.

Data analysis. The statistical analyses were performed using the ExpDes.pt-package from the $\mathrm{R}$ statistical software. The results of attack by $X$. compactus were subjected to univariate Analysis of Variance (ANOVA) to secure an overall error level of $P<0.05$. All multiple pairwise comparisons, performed when necessary, were performed using the Tukey's test $(P<0.05)$.

\section{RESULTS AND DISCUSSION}

Occurrence of $X$. compactus in robusta coffee in Rondônia state. This is the first record of $X$. compactus on robusta coffee $C$. canephora in Rondônia state, Brazil (Figure 1). Aside from the presence of injury on the plagiotropic branches, it was found observed a high incidence of attack on the vegetative orthotropic branches of clones present in the field; moreover, it was possible to observe scars (Figure 2). 


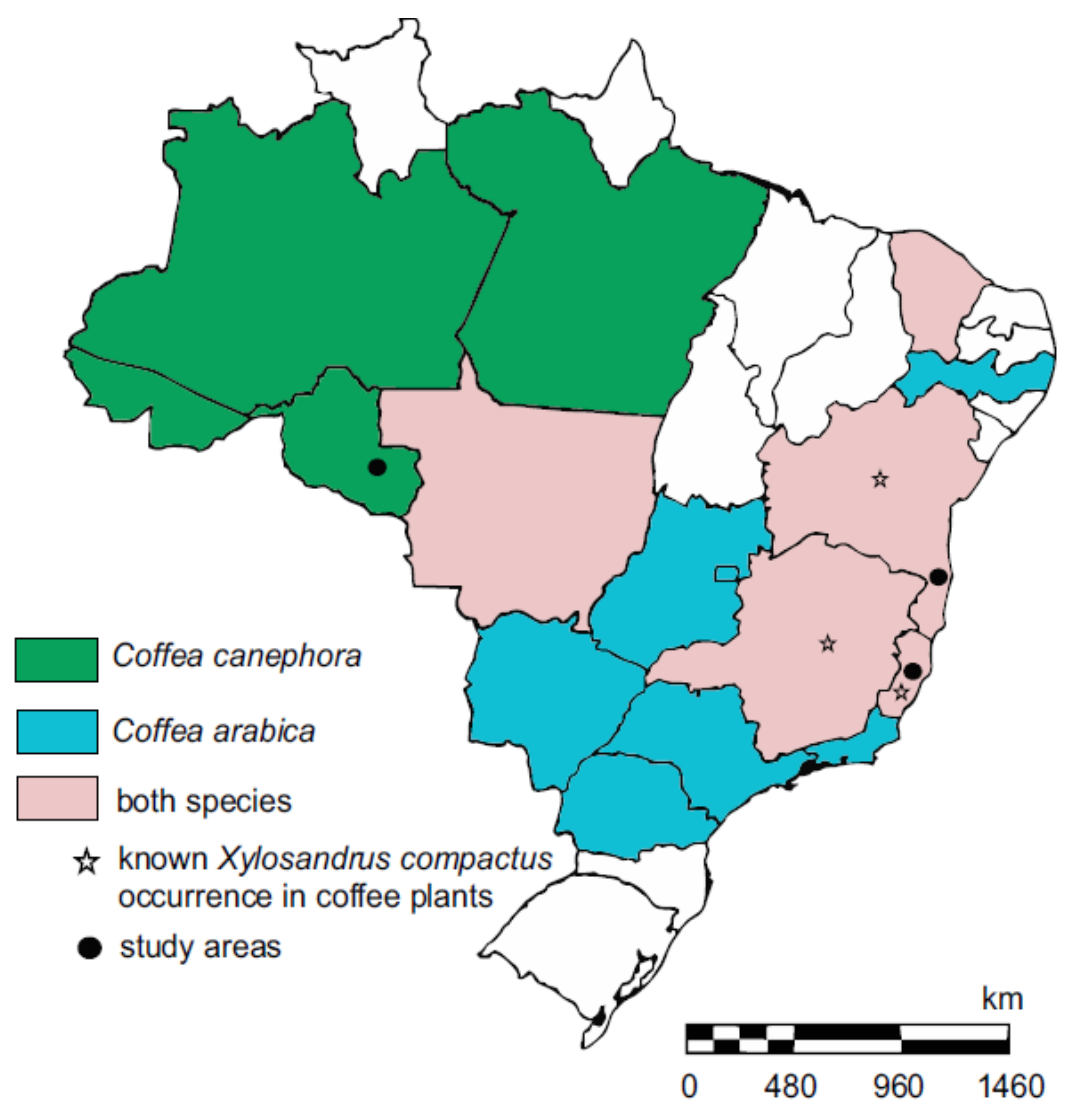

Figure 1. Map of coffee production areas in Brazil and areas with X. compactus occurrence.

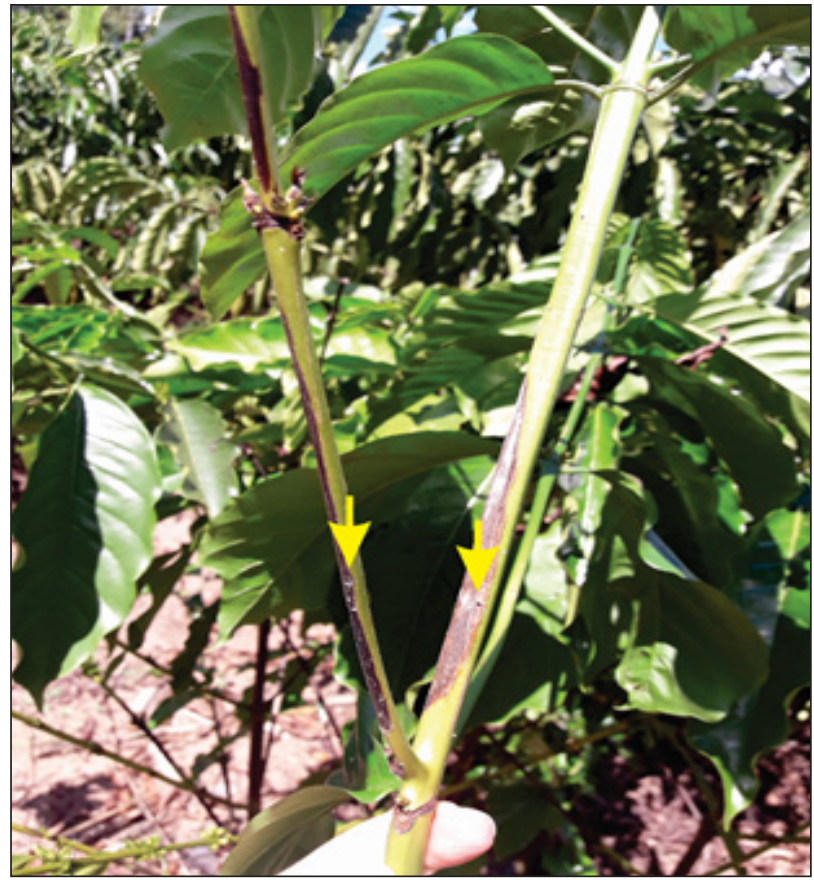

Figure 2. Xylosandrus compactus damage in vegetative orthotropic branch in Rondônia state.
Injury caused by $X$. compactus in robusta coffee. It was observed the attack in the production and vegetative orthotropic branches (Figure 3). The damage caused by $X$. compactus to the plagiotropic branches was recorded and described. Infestation of this insect results in an extensive tunneling within the branches, and the limitation of sap flow leads to the wilting of the branch, which serves as the main symptom of disease (Figure 4a). It was observed that entrance tunnels are excavated by females in plagiotropic branches (Figure 4b). The female $X$. compactus is of a shiny black color, lays eggs inside the gallery and remains in the entrance hole throughout the brood development (Figure 4c, Figure 4d and Figure 5). 


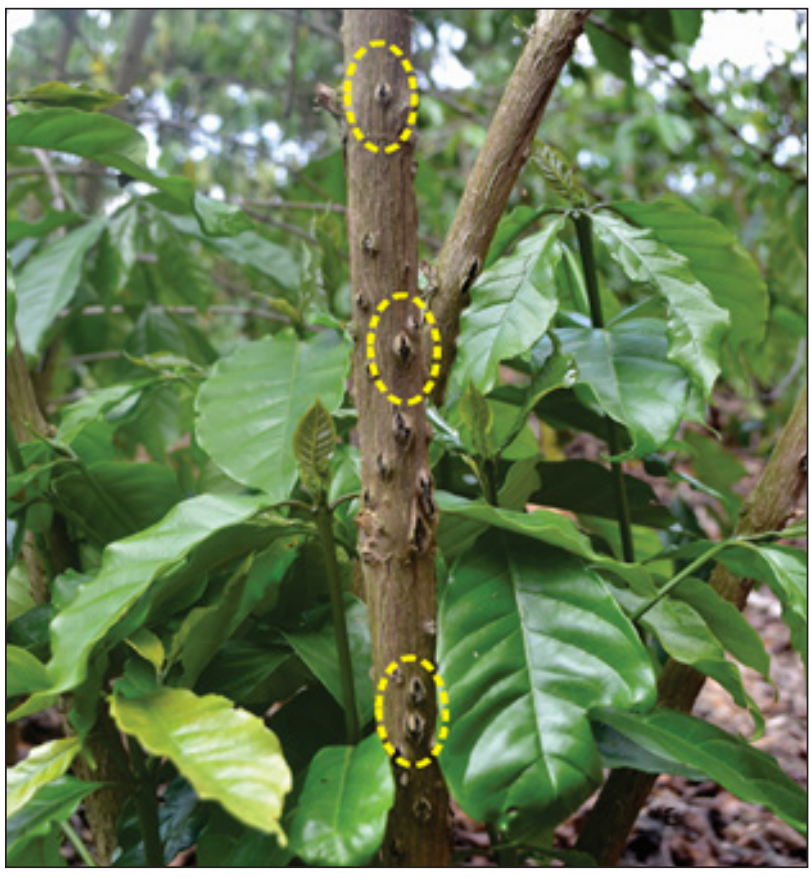

Figure 3. Xylosandrus compactus damage in orthotropic branch in Espírito Santo state.
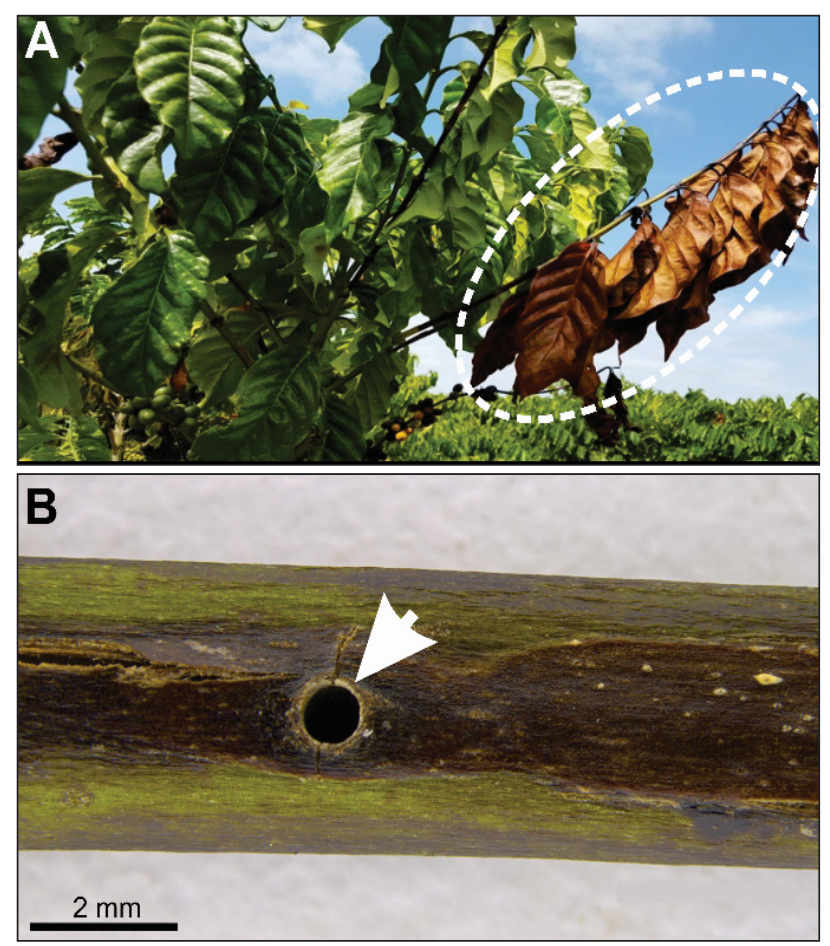

The temporal sequence registered in X-ray images showed the complete development and the movement of the insect inside plagiotropic branches (Figure 5). Black twig borer females initially cause severe mechanical damage in the host plant due to excavation of the gallery, which consequently blocks the passage of sap. Before the female lays eggs, the ambrosia fungus begins to develop inside the gallery, which may be phytopathogenic. The ambrosia fungus serves a food source for the offspring. After egg deposition, the female remains at the entrance to the gallery, and blocks it until the larvae develop into pupa. We registered all the development periods of the insect (egg to adult) inside fifteen galleries within 24 days (Figure 5).
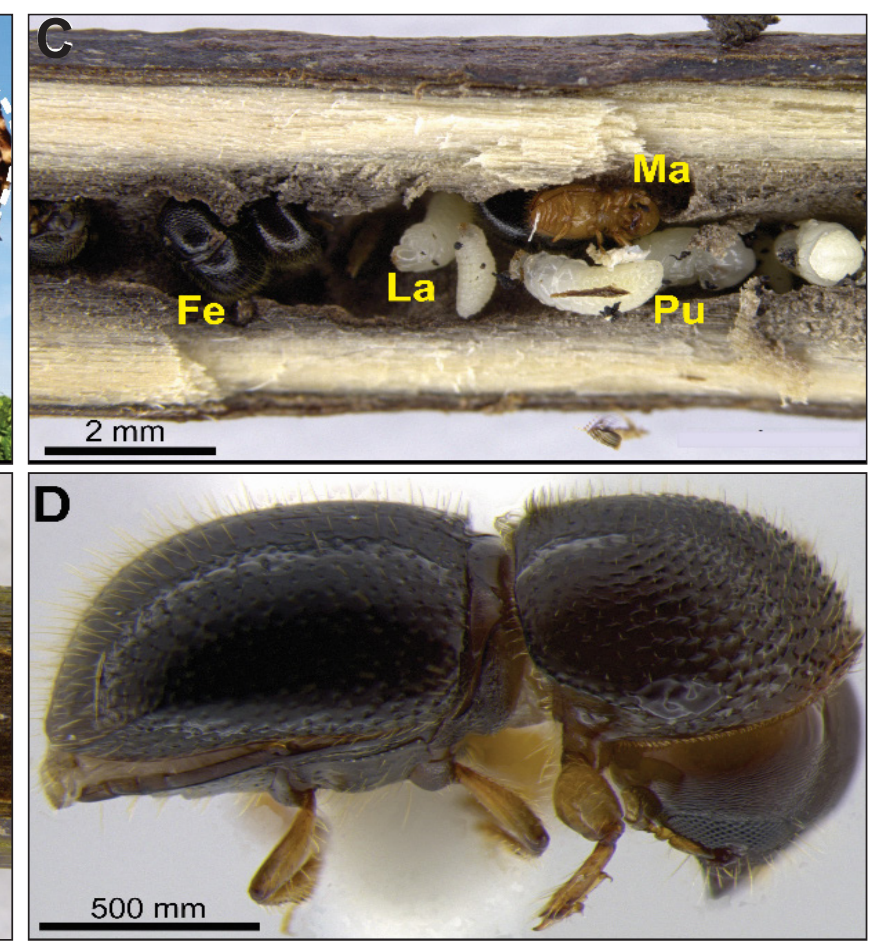

Figure 4. Xylosandrus compactus injury in coffee robusta (Coffea canephora). (a) Plagiotropic branch dry (white circle) after the insect attack in the field. (b) Entrance hole (white arrow) built by beetle female. (c) Larvae (La), pupae (Pu) and adults (Ad) inside the gallery. (d) X. compactus female. 


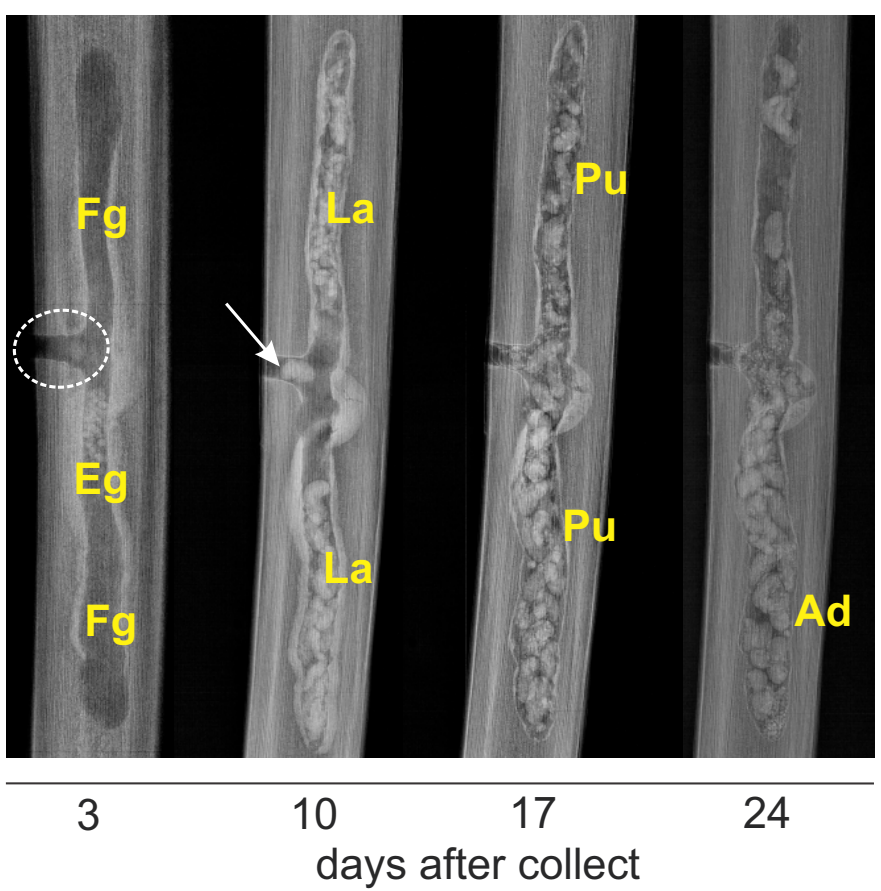

Figure 5. Representative temporal sequence of X-ray pictures showing the complete development of egg (Eg), larva (La), pupa (Pu) and adult (Ad) and movement of $X$. compactus inside plagiotropic branches. It is possible to see the beetle female (white arrow) in the hole entrance (white circle) and the fungus (Fg) cultivated inside the gallery as a food source for the offspring.

Injured genotypes and new host plants in Espírito Santo state. In all the genotypes evaluated, tunnel entrance was observed in plagiotropic branches. However, there are significant differences in the number of attacked branches among the genotypes $(F$ $=7.94, d f=9.27, P<0.001$; Figure 6). The highest rate of injury was observed in the G20 genotype with $29.5( \pm 9.89)$ attacked branches. The G2, G6, G8, G24, G41, G48, G50, G51, and G52 genotypes had a lower rate of injury, with less than 20 attacked branches (Figure 6). There were no differences in the number of attacked vegetative orthotropic branches among all genotypes (G2, G6, G8, G20, G24, G41, G48, G50, G51 and G52) ( $F=$ 1.63, $d f=9,27, P=0.158)$. 
injured plagiotropic branches

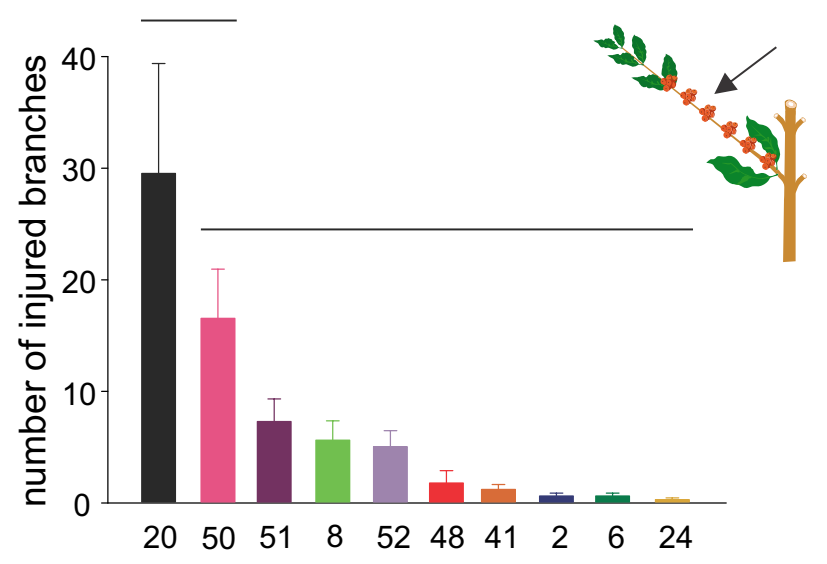

Figure 6. Injury caused by X. compactus in different genotypes of Coffea canephora. Average ( \pm $\mathrm{SE}$ ) of injured plagiotropic branches (production branches). Mean values grouped under the same horizontal line are not significantly different.

In order to report the native tree species hosts of $X$. compactus, some materials close to the coffee cultivation were collected wherein symptoms of the attack were observed with holes in branches; afterwards, the reproductive materials were analyzed, and the species was confirmed. It was found that there are four native tree species hosts of $X$. compactus, that correspond to, Almeidea rubra (A.St.-Hil.) (Rutacea), Alseis floribunda (Schott) (Rubiacaea), Plinia grandifolia (Mattos) (Myrtacea) and Casearia sylvestris (Swartz) (Salicaceae).

Even though the black twig borer currently occurs in the main robusta coffee producing areas in Brazil, the presence of this pest is still neglected, which may lead to a reduction in productivity in a short period of time. In Africa, $X$. compactus has recently been declared a threat to robusta coffee production, causing losses of US\$ 40 million in exports per year (Kagezi et al., 2014; Egonyu et al., 2016; Bukomeko et al., 2018;). The results revealed that $X$. compactus attacks either orthotropic or plagiotropic branches. Furthermore, the attack in vegetative branches (i.e., shoots in development) has not been previously reported in literature.

The greatest injury occurs when females excavate galleries and introduce the ambrosia fungus, which leads to wilting and the subsequent drying of the branches (Greco \& Wright, 2015). Thus, the plagiotropic branches may present reduced growth and, in some cases, interrupt the formation of floral buds, compromising reproduction (Hara \& Beardsley, 1979).

In some areas, the cyclic pruning program for conilon coffee (CPPCC) has been used in coffee crops (Verdin Filho et al., 2014, Verdin Filho et al., 2016). This technique consists of determining the correct number of orthotropic branches per area and stimulates the formation of new branches and more photosynthetically active leaves. Hence, the success of this program depends on the growth of new orthotropic branches (i.e., 
shoots) (Verdin Filho et al., 2014). In tropical regions, the populational peak of $X$. compactus adults inside galleries occurs between August and September (Egonyu et al., 2016), and this period coincides with the recommendation of the pruning program, which says that the peak occurs soon after harvest and before the first flowering (Fonseca et al., 2016).

In the field findings, attacks on orthotropic branches had not yet been reported in literature, which reinforces the problems that can be associated with $X$. compactus attacks in robusta coffee. Additionally, among ambrosia beetles, $X$. compactus is one of the few that attacks both healthy plants and plants that are under stress conditions caused by drought, recent transplanting or pruning (Masuya, 2007). In recent years the application of pruning program has been studied in $C$. arabica, in areas where $X$. compactus occurrence is reported (Verdin Filho et al., 2016).

Another problem is pest recognition and control in the field. Reports indicate that this insect is commonly confused with the coffee berry borer Hypothenemus hampei Ferrari 1867 (Coleoptera: Curculionidae), and preventive applications in the field using insecticides have been carried out according to recommendations for the coffee berry borer. Although pyrethroid applications to trunks and branches during peak adult flight periods are among the control methods used in the other regions where the pest occurs (Mizell and Riddle, 1998), these chemicals are not effective against $X$. compactus because it is protected inside the galleries within the plant, and the death of twigs may limit the movement of systemic insecticides into the galleries constructed by $X$. compactus.

Most of the genotypes G2, G6, G8, G24, G41, G48, G50, G51, and G52 were promising for selection studies involving genotypic and phenotypic characteristics that would help confer pest some resistance. These genotypes present phenotypic characteristics, such as plagiotropic woody branches, which may be associated with the lower observed number of attacks on either orthotropic or plagiotropic branches. In the production of robusta coffee, which involves the selection of different plant clones, it is recommended to use at least eight clones with desirable traits, such as drought tolerance, productivity and fruit ripening homogeneity (Ferrão et al., 2008). However, studies on the traits that confer pest resistance have been mainly focused on the coffee berry borer, H. hampei (Guerreiro Filho and Mazzafera, 2003). In this study, the G20 genotype is less preferred by $X$. compactus. Thus, the use of this genetic material should be taken into account in order to preserve them and in the future be introduced into breeding programs for robusta coffee.

The findings in this research, combined with the current lack of effective management tools for $X$. compactus, makes this pest an important area of study. There is a need for more studies that seek to associate pest behavior as dispersion and attraction by volatiles with control strategies, as are used with the coffee berry borer, H. hampei (Burbano et al., 2012; Jaramillo et al., 2013; VanDerLaan and Ginzel, 2013). Few previous studies have examined susceptibility to insecticides and natural enemies as a method to control $X$. compactus and other ambrosia beetles (Peña et al., 2011; Reding et al., 2013; Greco and Wright, 2015; Jones and Paine, 2018), thus making our study novel and of importance.

\section{CONCLUSION}

Xylosandrus compactus occurs in the main robusta coffee producing areas in Brazil, and 
that this insect presents different behaviors that can hinder its control in the field. The genotypes G24 and G41 exhibited a lower occurrence rate of $X$. compactus compared to genotypes G2, G6, G8, G20, G48, G50, G51, and G52. Furthermore, four native tree species are hosts of $X$. compactus. Finally, the presence of $X$. compactus may represent a threat to robusta coffee production in Brazil and may become a limiting factor for coffee production.

\section{ACKNOWLEDGEMENTS}

The authors would like to thank the National Council of Scientific and Technological Development (CNPq) and Coordenação de Aperfeiçoamento de Pessoal de Nível Superior - Brasil (CAPES) for funding. We thank the Corporation for Rural Extension and Technical Assistance of the state of Rondônia (EMATER - RO) and Agronomist Juliano Almeida de Souza (Agrisal Serviços Agropecuária Ltda, Eunápolis - BA) for collecting the insect specimens, the Institute of Espírito Santo for Research and Technical Assistance and Rural Extension (Incaper) for being able to use the Experimental Field in Marilândia - ES, Msc. Hugo Leoncini Rainho for the identification of the insect specimens and Dr. Amélia C. Túler for identification of the tree species. We also thank Dr. Raul Narciso C. Guedes (UFV) and Dr. José Maurício S. Bento (Laboratory of Chemical Ecology and Insect Behaviour - INCT- Semiochemicals in Agriculture/ESALQ-USP) and their coworkers for allowing the use of the X-ray and video imaging facilities.

Conflict of interest: The authors declare that there is no conflict of interest.

\section{BIBLIOGRAPHIC REFERENCES}

Batra, L. R. (1985). Ambrosia beetles and their associated fungi: Research trends and techniques. Proceedings: Plant Sciences. 94(12): 137-148.

Bhat, S. S. \& Sreedharan, K. (1988). Association of Ambrosiella xylebori Brader, with the shot-hole borer Xylosandrus compactus Eichhoff, a pest of robusta coffee. Journal of Coffee Research. 18(1): 54-57.

Brader, L. (1964). Étude de la relation entre le scolyte des rameaux du caféir, Xyleborus compactus Eichh. (X. morstatti Hag.), et sa plantehôte.Recovered from https://library. wur.nl/WebQuery/wurpubs/525661

Bukomeko, H., Jassogne, L., Kagezi, G.H., Mukasa, D. \& Vaast, P. (2018). Influence of shaded systems on Xylosandrus compactus infestation in Robusta coffee along a rainfall gradient in Uganda. Agricultural and Forest Entomology. 20(3): 327-333. doi: 10.1111/afe.12265

Burbano, E., Wright, M., Gillette, N., Mori, S., Dudley, N., Jones, T. \& Kaufmann, M. (2012). Efficacy of traps, lures, and repellents for Xylosandrus compactus (Coleoptera: Curculionidae) and other ambrosia beetles on Coffea arabica plantations and Acacia koa nurseries in Hawaii. Environmental Entomology. 41(1): 133-140. doi: $10.1603 /$ EN11112

Carvalho, J. E. U., Muller, C. H., Benchimol, R. L, Kate, A. K. \& Alves, R. M. (1999). Copoasu [Theobroma grandiflorum (Willd. Ex Spreng.) Shum.]: cultivo y utilización, Manual Técnico. Brasil: Secretaria Pro-Tempore del Tratado de Cooperación Amazónica, FAO. 142p.

CONAB - Companhia Nacional de Abastecimiento. (2018).Companhia Nacional de Abastecimento, Café, Safra 2018 - Quarto levantamento, dezembro 2018. recovered from https://www. conab.gov.br/info-agro/safras/cafe

Dixon, W. N., Woodruff, R. E. \& Foltz, J. L. (2003). Black twig borer, Xylosandrus compactus 
(Eichhoff) (Insecta: Coleoptera: Curculionidae: Scolytinae). Recovered from https://edis.ifas. ufl.edu/in577

Egonyu, J. P., Ahumuza, G. \& Ogari, I. (2016). Population dynamics of Xylosandrus compactus (Coleoptera: Curculionidae: Scolytinae) on Coffea canephora in the Lake Victoria Crescent agroecological zone of Uganda. African Zoology. 51(3): 121-126. doi: $10.1080 / 15627020.2016 .1215262$

Egonyu, J. P., Baguma, J., Ogari, I., Ahumuza, G. \& Ddumba, G. (2017). Host preference by the twig borer Xylosandrus compactus (Coleoptera: Scolytidae) and simulated influence of shade trees on its populations. International Journal of Tropical Insect Science. 37(3): 183-188. doi: $10.1017 / \mathrm{S} 174275841700008 \mathrm{X}$

Egonyu, J. P. \& Torto, B. (2018). Responses of the ambrosia beetle Xylosandrus compactus (Coleoptera: Curculionidea: Scolytinae) to volatile constituents of its symbiotic fungus Fusarium solani (Hypocreales: Nectriaceae). Arthropod-Plant Interactions. 12(1): 9-20. doi: 10.1007/ s11829-017-9552-2

Ferrão, R. G., Cruz, C. D., Ferreira, A., Cecon, P. R., Ferrão, M. A. G., Fonseca, A. F. A., Carneiro, P. C. S. \& Silva, M. F. (2008). Genetic parameters in Conilon coffee. Pesquisa Agropecuária Brasileira. 43(1): 61-69. doi: 10.1590/S0100204X2008000100009

Fonseca, A. F. A., Ferrão, R. G., Lani, J. A., Ferrão, M. A. G., Volpi, P. S., Verdin Filho, A. C., Ronchi, C. P. \& Guarçoni, MA. (2016). Manejo da Cultura do Café Conilon: Espaçamento, Densidade de Plantio e Podas. In R. G. Ferrão, A. F. A. Fonseca, M. A. G. Ferrão \& L. H. Muner (Eds), Café conilon (pp. 256-277). Vitória: Incaper.

Fornazier, M. J., Martins, D. S., Fanton, C. J. \& Benassi, V. L. R. M. (2016). Manejo de Pragas do Café Conilon. In: R. G. Ferrão, A. F. A. Fonseca, M. A. G. Ferrão \& Muner LH (Eds). Café conilon. (pp. 405-449). Vitória: Incaper.

Garonna, A. P., Dole, S. A., Saracino, A., Mazzoleni, S. \& Cristinzio, G. (2012). First record of the black twig borer Xylosandrus compactus (Eichhoff) (Coleoptera: Curculionidae, Scolytinae) from Europe. Zootaxa. 3251(1): 64-68.
Greco, E. \& Wright, M. G. (2015). Ecology, biology, and management of Xylosandrus compactus (Coleoptera: Curculionidae: Scolytinae) with emphasis on coffee in Hawaii. Journal of Integrated Pest Management. 6(1): 7. doi: 10.1093/jipm/pmv007

Guerreiro Filho, O. \& Mazzafera. P. (2003). Caffeine and resistance of coffee to the berry borer Hypothenemus hampei (Coleoptera: Scolytidae). Journal of Agricultural and Food Chemistry. 51(24): 6987-6991. doi:10.1021/ jf0347968

Haddi, K., Oliveira, E. E., Faroni, L. R. A., Guedes, D. C. \& Miranda, N. N. S. (2015). Sublethal exposure to clove and cinnamon essential oils induces hormetic-like responses and disturbs behavioral and respiratory responses in Sitophilus zeamais (Coleoptera: Curculionidae). Journal of Economic Entomology. 108(6): 28152822. doi:10.1093/jee/tov255

Hara, A. H. \& Beardsley, J. W. (1979). The biology of the black twig borer, Xylosandrus compactus (Eichhoff), in Hawaii. Proceedings of the Hawaiian Entomological Society, 13(1): 55-70.

Jaramillo, J., Torto, B., Mwenda, D., Troeger, A., Borgemeister, C., Poehling, H. M. \& Francke, W. (2013). Coffee berry borer joins bark beetles in coffee klatch. PLoS One, 8(9): e74277. doi: 10.1371/journal.pone.0074277

Jones, M. E. \& Paine, T. D. (2018). Potential pesticides for control of a recently introduced ambrosia beetle (Euwallacea sp.) in southern California. Journal Pest Science. 91(1): 237246. doi: 10.1007/s10340-017-0866-8

Kagezi, G., Kucel, P., Egonyu, J., Kyamanywa, S., Karungi, J., Pinard, F., Jaramillo, J., van Asten, P., Wagoire, W. \& Ngabirano, H. (2014). Published. A review of the pest status and research progress on the black coffee twig borer, Xylosandrus compactus (Eichhoff) in Uganda. Recovered from: http://agritrop. cirad.fr/579968/

Masuya, H. (2007). Note on the dieback of Cornus florida caused by Xylosandrus compactus. Bulletin of the Forestry and Forest Products Research Institute (Japan). 6(1): 59-63. 
Túler et al.- Xylosandrus compactus impairs coffee plants.

Mendes, A. C. B., Garcia, J. J. S. \& Rosário, A. F. S. (1979). Insetos nocivos ao cacaueiro na Amazônia brasileira, (Comunicado Técnico Especial, 1). Belém: Comissão Executiva do Plano da Lavoura Cacaueira, Departamento Especial da Amazônia, 34p.

Mizell, R. F. \& Riddle, T. C. (1998). Evaluation of insecticides to control the Asian ambrosia beetle, Xylosandrus crassiusculus. Recovered from: https://sna.org/Resources/ Documents/04resprocsec03.pdf

Ngoan, N., Wilkinson, R., Short, D., Moses, C. \& Mangold, J. (1976). Biology of an introduced ambrosia beetle, Xylosandrus compactus, in Florida. Annals of the Entomological Society of America. 69(5): 872-876. doi: 10.1093/ aesa/69.5.872

Oliveira, C. M., Flechtmann, C. A. H. \& Frizzas, M. R. (2008). First record of Xylosandrus compactus (Eichhoff) (Coleoptera: Curculionidae: Scolytinae) on soursop, Annona muricata L. (Annonaceae) in Brazil, with a list of host plants. The Coleopterists Bulletin. 62(1): 45-48. doi: $10.1649 / 1039.1$

Peixoto, A. L. \& Maia, L. C. (2013). Manual de Procedimentos para Herbários. INCT-Herbário virtual para a Flora e os Fungos. Recife: Editora Universitária UFPE.

Peña, J. E., Crane, J. H., Capinera, J. L., Duncan, R. E., Kendra, P. E., Ploetz, R. C., McLean, S., Brar, G., Thomas, M. C. \& Cave, R. D. (2011). Chemical control of the redbay ambrosia beetle, Xyleborus glabratus, and other Scolytinae (Coleoptera: Curculionidae). Florida Entomologist. 94(4): 882-897. doi: 10.1653/024.094.0424

Rabaglia, R. J., Dole, S. A. \& Cognato, A. I. (2006). Review of American Xyleborina (Coleoptera: Curculionidae: Scolytinae) occurring north of Mexico, with an illustrated key. Annals of the Entomological Society of America. 99(6): 1034-1056. doi 0.1603/0013-8746(2006)99[1034:ROAXCC]2 $.0 . \mathrm{CO} ; 2$

Reding, M. E., Oliver, J. B., Schultz, P. B., Ranger, C. M. \& Youssef, N. N. (2013). Ethanol injection of ornamental trees facilitates testing insec- ticide efficacy against ambrosia beetles (Coleoptera: Curculionidae: Scolytinae). Journal of Economic Entomology, 106(1): 289-298. doi: 10.1603/EC12315

VanDerLaan, N. R. \& Ginzel, M. D. (2013). The capacity of conophthorin to enhance the attraction of two Xylosandrus species (Coleoptera: Curculionidae: Scolytinae) to ethanol and the efficacy of verbenone as a deterrent. Agricultural and Forest Entomology. 15(4): 391-397. doi: 10.1111/afe.12026

Thiers, B. (2015). Index Herbariorum: a global directory of public herbaria and associated staff. New York Botanical Garden's Virtual Herbarium. Retrieved from http://sweetgum. nybg.org/ih

Vannini, A., Contarini, M., Faccoli, M., Valle, M. D., Rodriguez, C., Mazzetto, T., Guarneri, D., Vettraino, A. \& Speranza, S. (2017). First report of the ambrosia beetle Xylosandrus compactus and associated fungi in the Mediterranean maquis in Italy, and new host-pestassociations. EPPO Bulletin, 47(1): 100-103. doi: 10.1111/ epp.12358

Verdin Filho, A. C., Tomaz, M. A., Ferrão, R. G., Ferrão, M. A. G., Fonseca, A. F. A. \& Rodrigues, W. N. (2014). Conilon coffee yield using the programmed pruning cycle and different cultivation densities. Coffee Science. 9(4): 489494.

Verdin Filho, A. C., Volpi, P. S., Ferrão, M. A. G., Ferrão, R. G., Mauri, A. L., Fonseca, A. F. A., Tristão, F. A. \& Andrade Júnior, S. (2016). New management technology for arabica coffee: the cyclic pruning program for arabica coffee. Coffee Science, 11(4): 475-483.

Wood, S. L. (1982). The bark and ambrosia beetles of North and Central America (Coleoptera: Scolytidae), a taxonomic monograph. Provo: Brigham Young University. 